\author{
GENNADII KOROLOV \\ Instytut Historii Ukrainy \\ Narodowej Akademii Nauk Ukrainy
}

\title{
„DWIE EUROPY ŚRODKOWE” OSKARA HALECKIEGO W „CIENIU IMPERIALIZMÓW”*
}

\begin{abstract}
Abstrakt: Autor niniejszego tekstu przeanalizował genezę koncepcji „dwóch Europ Środkowych" wybitnego polskiego historyka Oskara Haleckiego (1891-1973), która powstała na bazie starej tradycji historiograficznej dotyczącej Europy Wschodniej oraz jako reakcja na położenie „między Niemcami a Rosją".

Słowa kluczowe: Europa Środkowa, imperializm, federalizm, granica europejska, narracja narodowa.
\end{abstract}

Abstract: The article presents an analysis of the genesis of the concept of "Dualism of Central Europe" formulated by the outstanding Polish historian Oskar Halecki (18911973) as a reflection on the historiographic tradition of Eastern Europe and reaction to the dichotomous political position "between Germany and Russia".

Keywords: Central Europe, imperialism, federalism, European divisions, national narrative.

Czy istnieje Europa Środkowa? Jakie są granice tego obszaru? Takie pytania dotyczące własnego regionu nurtowały historyków jeszcze na początku XX w. ${ }^{1}$ Dlaczego Europa „Centralna” przegrała ze „Środkową"? Jaki był właściwie wymiar emancypacji regionu?

Są to pytania, które inspirowały znanego polskiego historyka Oskara Haleckiego (1891-1973), uważanego za autora pojęcia „Europa

* Chciałbym bardzo podziękować Fundacji im. Krzysztofa Skubiszewskiego i Niemieckiemu Instytutu Historycznemu w Warszawie za daną mi możliwość przeprowadzenia badań w Polsce, oraz Rafałowi Stobieckiemu (Uniwersytet Łódzki) za cenne uwagi i poprawki do mojego tekstu.

1 S. Troebst, What's in a Historical Region? A Teutonic Perspective, „European Review of History" 10, 2003, 2, s. 173-188; P. Wandycz, O historycznej tożsamości Europy Środkowo-Wschodniej, „Tygodnik Powszechny” 1987, 18. 
Środkowo-Wschodnia"2. W artykule tym postaramy się przeanalizować istotę, ewolucję i instrumentalizację tej definicji w pracach Haleckiego oraz wyjaśnić rolę pojęć „granica historyczna” i „federalizm”. W szczególności omówimy główne elementy jego koncepcji „dwóch Europ Środkowych"3 która powstała jako alternatywa brytyjskiej, francuskiej i niemieckiej percepcji wschodu Europy ${ }^{4}$.

Rozpocznijmy od wyjaśnienia pojęć. W twórczości Haleckiego wyróżniamy kilka podstawowych mitów historiograficznych (w rozumieniu Jerzego Topolskiego), które wpływały na rozwój jego badań. Są to „idea jagiellońska”, „pogranicze Zachodu” i „Europa Środkowa”. Były to przede wszystkim narzędzia opisu historii, które wykorzystywał on jako podstawę teoretyczną do wzmocnienia własnej argumentacji. Pod względem merytorycznym ważne jest zrozumienie, jak formułował on własny język opisu przeszłości. Taka analiza będzie opierać się na przedstawieniu, w jaki sposób Halecki traktował obraz „innego”, jak konstruował granice cywilizacyjne i jak odnosił się do "cieni imperializmu”, które, jego zdaniem, wpływały na dzieje Europy Środkowo-Wschodniej par excellence.

W historiografii polskiej zagadnienie to od dawna jest przedmiotem dyskusji. Koncepcje i idee Haleckiego dotyczące Europy Środkowo-Wschodniej stały się głównym tematem rozważań polskich i zagranicznych historyków na stronach specjalnego numeru „Kwartalnika Historycznego” z 2013 r. ${ }^{5}$ Praktycznie wszyscy polscy autorzy (Maciej Górny, Dariusz Kołodziejczyk, Jerzy Kłoczowski, Tomasz Kizwalter, Marek Kornat) ${ }^{6}$,

${ }^{2}$ Wymienimy najważniejsze badania spuścizny Haleckiego i jego wizji historycznej: R. Stobiecki, Twórczość emigracyjna Oskara Haleckiego (1891-1973). Próba charakterystyki, w: Studia z dziejów Polski i Europy w XIX i XX wieku. Księga dedykowana Profesorowi Piotrowi Stefanowi Wandyczowi, red. J. Faryś, R. Nir, M. Szczerbiński, Gorzów Wielkopolski 2004, s. 581-592; idem, Historycy polscy wobec wyzwań XX wieku, Poznań 2014, s. 161-204; J. Cisek, Oskar Halecki. Historyk. Szermierz Wolności, Warszawa 2009, s. 7-45; K. Błachowska, Oskar Halecki (1891-1973), w: O. Halecki, Dzieje Unii Jagiellońskiej, t. 2: W XVI wieku, oprac. K. Błachowska, Warszawa 2013, s. 387-406.

3 Zagadnienie „dwóch Europ Środkowych" w twórczości Haleckiego rozpatrywał w swojej monografii historyk Sławomir Łukasiewicz, Trzecia Europa. Polska myśl federalistyczna w Stanach Zjednoczonych 1940-1971, Warszawa-Lublin 2010, s. 316-317; M. Kornat, Historyk Europy Środkowo-Wschodniej. Oskar Halecki (1891-1973) w nauce i życiu Polski, w: Historik v proměnách doby a prostředi 20. stoleti, red. J. Hanuš, R. Vlček, Brno 2009, s. 305338; M. Morawiec, Oskar Halecki, w: Europa-Historiker. Ein biographisches Handbuch, red. H. Duchhardt, Göttingen 2006, s. 215-239.

${ }^{4}$ Zob. L. Wolff, Inventing Eastern Europe. The Map of Civilization on the Mind of the Enlightenment, Stanford Calif. 1994.

${ }^{5}$ KH 120, 2013, 4, 659-1003.

${ }^{6}$ Ibidem, s. 802, 827, 833, 853 etc. 
a także rosyjski historyk Aleksiej Miller ${ }^{7}$, wskazywali na Haleckiego przy określaniu istoty pojęcia „Europa Środkowo-Wschodnia”. Można skonstatować, że takie podejście już od dwóch dziesięcioleci istnieje jako swoisty szablon. Problem polega na tym, jak postrzegać ten region: jako zawsze istniejącą rzeczywistość czy jako pojęcie wymyślone/wyobrażone? Czy warto dzisiaj rezygnować z regionalnych podziałów Europy? Maciej Górny odpowiada, że „Europa Środkowo-Wschodnia dysponuje potencjałem, dzięki któremu nie «przegra» z historią globalną, historią Europy czy też peryferii Zachodu"8. Podobne zdanie głosił zarówno sam Halecki, jak i obecnie Piotr Wandycz oraz praktycznie większość amerykańskich historyków pochodzenia wschodnioeuropejskiego. Jednak jeśli jest problem w ocenie potencjału naukowego, to dlaczego historyk musi przyjmować cywilizacyjne i kulturowe podziały świata i Europy? Takie podziały są niepotrzebne i nieobiektywne. $\mathrm{W}$ oparciu o to założenie postaramy się przeprowadzić naszą analizę.

Po raz pierwszy o Haleckim jako autorze definicji Europy Środkowo-Wschodniej napisał Jerzy Kłoczowski ${ }^{9}$. Janusz Cisek również uważa, że bez wątpienia to właśnie Halecki odegrał główną rolę w zakorzenieniu tego pojęcia $\mathrm{w}$ dyskursie akademickim i politycznym ${ }^{10}$. Jest oczywiste, że konkluzja Ciska wiąże się z odpowiednią instrumentalizacją tej definicji w postrzeganiu historyków polskich. Zrozumiałe są także przyczyny popularności tego pojęcia, na którą wpływały krytyczne oceny dziejów krajów „demokracji ludowej” i historiograficzne dominowanie podziału Europy na Zachodnią i Wschodnią, a więc odrębne ich postrzeganie. Jednak stworzenie systemu socjalistycznego, który przeciwstawiał się światu zachodniemu i kapitalistycznemu, było postrzegane jako ustanowienie rosyjskiej (imperialnej) dominacji.

Oskara Haleckiego można określić jako polskiego historyka chorwackiego i ruskiego pochodzenia. Urodził się w Wiedniu w 1891 r. w rodzinie generała armii austriackiej. W latach 1909-1914 studiował na Uniwersytecie Jagiellońskim, gdzie obronił pracę doktorską (1913) i habilitacyjną (1915). Do 1918 r. pracował jako Privatdozent w Katedrze

7 A. Miller, Koncepcje regionalnego podziału Europy to przedmiot badań geografii mentalnej. I tyle, KH 120, 2013, 4, s. 863.

${ }^{8}$ M. Górny, Użyteczność i granice. Europa Środkowo-Wschodnia jako narzędzie badawcze, KH 120, 2013, 4, s. 808.

9 J. Kłoczowski, Europa Środkowowschodnia w historiografii krajów regionu, Lublin 1993, s. 16; idem, Oskar Halecki i jego walka o miejsce Polski w Europie, w: Z dziejów polityki i dyplomacji. Studia poświęcone pamięci Edwarda hr. Raczyńskiego, Prezydenta Rzeczypospolitej Polskiej na wychodźstwie, red. H. Bułhak, Warszawa 1994, s. 397-406.

10 J. Cisek, Oskar Halecki. Historyk, s. 7-45. 
Nauk Pomocniczych Historii. Planował założyć Katedrę Dziejów Europy Wschodniej, jednak po odzyskaniu niepodległości wyjechał do Warszawy. Tam na nowym uniwersytecie objął Katedrę Historii Europy Wschodniej $^{11}$. W 1940 r. był organizatorem Uniwersytetu Polskiego Zagranicą w Paryżu, następnie wyemigrował do USA, gdzie pracował jako profesor historii wschodnioeuropejskiej na Fordham University. Był również współzałożycielem i dyrektorem Polskiego Instytutu Naukowego w Nowym Jorku (w latach 1942-1953 był dyrektorem, a 1953-1962 prezesem). Zmarł w 1973 r. w White Plains. W oficjalnej historiografii Polskiej Rzeczypospolitej Ludowej był krytykowany za klerykalizm i czołobitność wobec Zachodu ${ }^{12}$.

Po przyjeździe do Warszawy jesienią 1918 r. Halecki zaangażował się w publicystykę polityczną. Już w grudniu jako młody specjalista przeszedł do służby dyplomatycznej, gdzie otrzymał stanowisko sekretarza generalnego Biura Prac Kongresowych Ministerstwa Spraw Zagranicznych i piastował je do lata 1919 r. ${ }^{13}$ Można stwierdzić, że dzięki jego pracy jako eksperta mogły powstać artykuły na temat „historycznych granic” Polski (zagadnienia, które będzie podstawą jego wizji „nowej” Europy). Jej oczywiste centrum to ziemie i spuścizna dawnej Rzeczypospolitej.

W eseju pod chwytliwym tytułem Ekspansja i tolerancja Halecki pisze o historycznym wymiarze Unii Jagiellońskiej, przedstawiając podstawy polskiej misji cywilizacyjnej na wschodzie. Na skutek tej ekspansji „nastąpiła wzajemna wymiana etnicznych i historycznych wartości”"14. Jego zdaniem, nawet "przyroda nie oddzieliła tych trzech narodów” (Polaków, Litwinów i Rusinów), lecz przeciwnie - splotła ich „ziemie ojczyste siecią rzek, historycznych dróg”. Ich położenie historyczne rozpatrywał w ramach opozycji „między Niemcami i Azją”. Pisał, że były one zagrożone „od zachodu naporem germańskim, który je wcześniej odparł od Bałtyku, od wschodu barbarzyństwem azjatyckich hord, które nie tylko zamknęły im drogę do drugiego morza, ale przeniknęły też swym zaborczym, despotycznym duchem wschodnią «zaleską» latorośl Rusi"15. Sposobem na wzmocnienie mocarstwowości Polski było według

11 AAN, zespół 14 (Ministerstwo Wyznań Religijnych i Oświecenia Publicznego, dalej: MWRiOP), sygn. 2810, Akta osobowe Oskara Haleckiego, k. 1.

12 J. Tazbir, Fałsz historyczny i zdrada narodu w pracach 0. Haleckiego, KH 60, 1953, 3, s. 177-178; K. Grzybowski, Anachroniczna historiozofia profesora Oskara Haleckiego, w: idem, Refleksje sceptyczne, t. 1, Kraków 1972, wyd. II, s. 65-76.

13 AAN, zespół 14 (MWRiOP), sygn. 2810, Akta osobowe Oskara Haleckiego, k. 42.

${ }^{14}$ O. Halecki, Ekspansya i tolerancya, w: Przyczyny upadku Polski. Odczyty, Kraków 1918, s. 75.

15 Ibidem. 
niego stworzenie federacji państw ${ }^{16}$. Polska, jego zdaniem, jest „jedną z najmłodszych córek łacińskiego Zachodu, zaniosła jego kulturę aż po Dźwinę i Dniepr"17. Na tej podstawie widział jej szczególną rolę we włączaniu Wschodu do świata łacińskiego.

W rezultacie, realizacja idei jagiellońskiej w formie unii polsko-litewskiej miała jedną zasadniczą wadę, która polega na nieuznawaniu ziem ruskich za trzecią część Rzeczypospolitej. W tej kwestii Halecki może być traktowany jako reprezentant ,jagiellońskiej” koncepcji dziejów Polski. Traktował jej historię jako realizację idei dobrowolnej współpracy Polski i Litwy w formie federacji demokratycznej ${ }^{18}$. Jego kolega Ludwik Kolankowski trzymał się innego podejścia: wyznaczał Polakom rolę „kulturtregerów", którą pełnili w stosunku do Litwinów, Ukraińców i Białorusinów ${ }^{19}$.

Temu zagadnieniu został poświęcony artykuł Haleckiego o podstawach historycznych ówczesnej polityki wschodniej, który ukazał się na łamach „Przeglądu Dyplomatycznego” w 1919 r. ${ }^{20}$ Zaczyna się on od sformułowań „Polska etnograficzna” i „właściwie Rosja”, które pomagają zrozumieć jego dalszą logikę argumentacji. W stosunku do ziem białoruskich i ukraińskich wykorzystywał on słowo „Ruś”, które było rozpowszechnione wśród polskich historyków do 1939 r. Wszystkie te określenia dotyczące Polski etnograficznej, Rosji i Rusi były charakterystyczne dla historyków, którzy przyjmowali „optymistyczną” koncepcję polskich dziejów. Unia jagiellońska przesunęła nie tylko „granice Polski, ale zarazem też granice zachodniej cywilizacji", które istniały do „rozbioru państwa polskiego”21. Halecki postrzega tu Polskę jako część Zachodu, utożsamiając z nim Rzeczpospolitą. Analizując dzieje Polski na wschodzie, dochodzi do wniosku, że jakiekolwiek pretensje Ukraińców i Rosjan do Galicji Wschodniej czy Chełmszczyzny „pozostają w zupełnej sprzeczności z prawami historycznymi Polski"22. Już wtedy postrzegał on Rzeczpospolitą jako terytorium Europy Wschodniej, ponieważ historycznie odróżniał Ruś od Moskiewszczyzny i od Rosji.

${ }^{16}$ Właśnie temu zagadnieniu zostało poświęcone dwutomowe dzieło Haleckiego: O. Halecki, Dzieje Unii Jagiellońskiej, t. 1: W wiekach średnich, t. 2: W XVI wieku, Kraków 1919-1920 (dalej cytowane to wydanie).

17 O. Halecki, Ekspansya i tolerancya, s. 76.

18 o. Halecki, Dzieje Unii Jagiellońskiej, t. 2, s. 340-341.

19 M. Górny, Przede wszystkim ma być naród. Marksistowskie historiografie w Europie Środkowo-Wschodniej, Warszawa 2007, s. 189.

20 O. Halecki, Wschodnia granica Polski w świetle historii, „Przegląd Dyplomatyczny” 1, 1919, 2, s. 45-57.

21 Ibidem, s. 45.

22 Ibidem, s. 56. 
Dlatego - zdaniem Haleckiego - Europa Wschodnia jako wspólnota historyczna i cywilizacyjna istniała zawsze, niezależnie od wpływów Rosji. Właśnie polityka wschodnia Józefa Piłsudskiego była nastawiona na przekształcanie dawnych zachodnich kresów Cesarstwa Rosyjskiego w nowe państwa narodowe, które powinny stać się naturalną barierą przeciw rozpowszechnianiu imperializmu. Stworzenie i zwycięstwo niepodległej zarówno Ukrainy, jak i Białorusi, może wstrzymać odrodzenie się imperialnych tendencji Rosji i pozwolić Europie zabezpieczyć swoje granice wschodnie przed wpływami azjatyckimi.

Za skuteczne narzędzie polskiej polityki wschodniej Halecki uważał federalizm, który miał być prawdziwą koncepcją obrony interesów narodowych. Występował tu jako zwolennik obozu Piłsudskiego. Jako historyk nie uważał on Polski, która odzyskała niepodległość w $1918 \mathrm{r}$. za „państwo nowe”23. Dlatego też apelował o odnowienie spuścizny jagiellońskiej w polityce, na arenie międzynarodowej i w życiu publicznym. Pod wpływem podpisania umowy Piłsudski-Petlura w kwietniu 1920 r. opublikował esej o znaczeniu Kijowa dla historii Polski i ówczesnej walki o granice na wschodzie, odwołując się do kategorii „sprawiedliwości historycznej” 24 . Doszedł do wniosku, że „także z murów Kijowa zsuwa się przygniatający cień ostatniego ćwierćtysiąclecia. Zsuwa go zaś, dokonywając wreszcie swego dawnego dzieła wyzwolenia i odrodzenia, wieńcząc go aktem pojednania, Rzeczypospolita Polska"25. Jak widać, w tym eseju znów pojawia się motyw dobroczynnej misji polskiej na Rusi.

Wszystko to pozwala twierdzić, że ówczesne teksty publicystyczne Haleckiego, jak i Dzieje Unii Jagiellońskiej, świadczą o jego pierwszych próbach utożsamiania Europy Wschodniej z historią dawnej Rzeczypospolitej. Wtedy jeszcze, uznając Europę Wschodnią za pojęcie czysto geograficzne, a nie cywilizacyjne, proponował, aby traktować ją jako granicę „między Niemcami i Rosją”. Takiego poglądu trzymał się aż do początku II wojny światowej. O tym świadczą jego polemiki i wygłoszone referaty na międzynarodowych kongresach historyków (Bruksela 1923, Oslo 1928, Warszawa 1933, Zurich 1938).

Wedle poglądów Haleckiego, Europa Wschodnia obejmuje terytorium dawnej Rzeczypospolitej i innych ziem na północ od Karpat, ponieważ takie rozszerzenie granic europejskich stało się możliwe po chrystianizacji

${ }^{23}$ M. Kornat, Profesor Oskar Halecki w życiu politycznym Polski i na forum międzynarodowym, w: Oskar Halecki i jego wizja Europy, t. 3, red. M. Dąbrowska, Warszawa-Łódź 2014, s. 275.

24 O. Halecki, Kijów a Polska, „Tygodnik Ilustrowany” 1920, 20, s. 382.

25 Ibidem. 
tego obszaru w IX i X w. ${ }^{26}$ Ruś Kijowska i Moskwa powstawały w oparciu o różne podstawy polityczne i etniczne. Państwo Moskiewskie zostało stworzone na zasadach ugrofińskich i dlatego wybrało inny kierunek rozwoju cywilizacyjnego i kulturowego, który jest związany z tradycjami azjatyckimi. „Państwa Kijowskiego” (w terminologii Haleckiego) nie należy traktować ani jako Rosji, ani jako Ukrainy, a raczej Ruthenię, która bliższa jest słowu „Ruś”, niż „Rosja”27. To było politycznie „niedojrzałe” terytorium Słowian wschodnich, na które Polska miała stały wpływ. Później, właśnie ziemie dawnej Rusi stały się terenem walk między Polską i Moskwą, które w szerokim kontekście historycznym są konfliktem cywilizacji.

W 1933 r. na międzynarodowym kongresie w Warszawie Halecki skrytykował czeskiego historyka Jaroslava Bidlo za geopolityczny determinizm w ocenie pojęcia „Europa Wschodnia”, proponując rozpatrywanie go na podstawie geograficznej ${ }^{28}$. Sceptycznie wyrażał się o dychotomii „między Bizancjum a Rzymem”, która, jego zdaniem, upraszcza historię Europy, przyjmował jednak tezę o jej kulturowym i religijnym podziale na świat bizantyjsko-słowiański i łaciński. Na tej podstawie mówił o przewartościowaniu pojęcia „Europy”, które wyraźnie nie pokrywa całego kontynentu $\mathrm{w}$ sensie geograficznym ${ }^{29}$. Tę kwestię uzasadniał przynależnością Polski do systemu wartości świata zachodniego. Jednocześnie podkreślał rolę Rzeczypospolitej w zmianach i w konstruowaniu granic europejskich na wschodzie. Dlatego rok później w opisywaniu dziejów Polski przeciwstawiał rewizjonizmowi tradycjonalizm, który powinien opierać się na tradycji narodowej i etyce chrześcijańskiej ${ }^{30}$.

Halecki przekonywał, że Europa Wschodnia w wymiarze cywilizacyjnym to zachodnie kresy Imperium Rosyjskiego, podobnie jak i niektóre ruskie regiony dawnej Rzeczypospolitej. Był to obszar historyczny, który każdy zamieszkujący go naród traktował jako swój. Halecki widział tu korzenie wybuchających konfliktów historycznych, przede wszystkim

${ }^{26}$ O. Halecki, L'histoire de l'Europe orientale. Sa division en époques, son milieu géographique et ses problèmes fondamentaux, w: La Pologne au V Congrès International des Sciences Historiques, Bruxelles 1923, Varsovie 1924, s. 73-94.

27 Ibidem, s. 79.

28 P. Wandycz, Oskar Halecki i jego koncepcja Europy Środkowo-Wschodniej, ,Rocznik Instytutu Europy Środkowo-Wschodniej” 5, 2007, s. 49. Debata ta została szczegółowo opisana w: idem, East European History and its meaning. The Halecki-Bidlo-Handelsman debate, w: Király Béla emlékkönyv. Háború és társadalom, red. P. Jónás, B.K Király, Budapest 1992, s. 308-321.

${ }^{29}$ Europa Współczesna, część ogólna. Rok akad. 1931-32, według wykładów prof. Oskara Haleckiego, Warszawa [1932?], s. 4.

30 O. Halecki, Czy potrzebna jest „rewizja” dziejów Polski, „Przegląd Powszechny” 204, 1934,612 , s. $313,314$. 
sporów terytorialnych. Traktował Rzeczpospolitą jako pierwszy ustrój demokratyczny i państwo federacyjne w średniowiecznej Europie, o czym świadczyły prawa i wolności grup społecznych ${ }^{31}$. Nie wskazywał tu swoich bezpośrednich poprzedników intelektualnych, ale jest oczywiste, że powtarzał interpretacje „optymistycznego" nurtu ówczesnej polskiej historiografii i publicystyki ${ }^{32}$. Ponadto, podobną interpretację Rusi Kijowskiej jako federacji demokratycznej przedstawiali na przykład historycy rosyjscy i ukraińscy w XIX w. ${ }^{33}$ Jak z tego wynika, dla Haleckiego federalizm był przede wszystkim narzędziem analitycznym do opisywania historii średniowiecznej, które pomaga w wyjaśnieniu dziejów Europy Środkowo-Wschodniej. I tak na przykład pisał, że rozwój państwa Jagiellonów w średniowieczu był początkiem tworzenia nowej republikańskiej Europy. Właśnie to była udana próba wcielenia elementów federacyjnych w historii europejskiej. Oprócz tego zauważył historyczną rolę Polski na wschodzie Europy, o czym świadczą „obiecujące próby politycznego związania z nim [„mocarstwem jagiellońskim"] wszystkich ziem między Bałtykiem a Morzem Czarnym, Niemcami a Wschodem moskiewsko-tatarsko-tureckim"34. To właśnie w tym kontekście Halecki powracał do idei antemurale, pisząc, że w „granicach Polski, Litwy i ich ziem rozkwitło ognisko kultury, które rozszerzyło niebywale zasięg cywilizacji łacińskiej Zachodu, łącząc ją z niektórymi, żywotnymi pierwiastkami wschodniej, greckiej" ${ }^{35}$. Rzeczpospolita według niego była nie tylko częścią Europy i Zachodu, ale ich „ostatnim bastionem" przed barbarzyńskim Wschodem. Pojawienie się średniowiecznej idei antemurale w czasach Haleckiego było odpowiedzią na utratę suwerenności przez Rzeczpospolitą ${ }^{36}$, a także istniała ona jako forma obrony tożsamości narodowej. Po odzyskaniu niepodległości stała się jednym z ideologicznych instrumentów polityki wschodniej prowadzonej w celu przywrócenia starych granic „historycznych”.

31 Zob. O. Halecki, Dzieje Unii Jagiellońskiej, t. 1 i 2.

32 Zob. M. Kornat, „Pesymizm” czy „optymizm”? Oskar Halecki a spór o wartość dziejowej spuścizny przedrozbiorowej Rzeczypospolitej w historiografii polskiej, w: Oskar Halecki i jego wizja Europy, t. 2, red. M. Dąbrowska, Warszawa-Łódź 2014, s. 67-90.

${ }_{33}$ Bardziej szczegółowo zagadnienie zasad federacyjnych Rusi Kijowskiej przedstawiono w: Н.И. Костомаров, Мысли о федеративном начале в Древней Руси, Из журнала „Основа”, Санкт Петербург 1961; М.С. Грушевський, Історія України-Руси: в $11 \mathrm{~m}$. 12 кн., t. 3, Київ 1993, s. 538.

${ }^{34}$ O. Halecki, Idea Jagiellońska, KH 51, 1937, 1-2, s. 509.

35 Ibidem.

${ }^{36}$ Genealogię idei antemurale zbadał polski historyk Janusz Tazbir, Od antemurale do przedmurza. Dzieje terminu, OiRP 29, 1984, s. 166-184; idem, Polskie przedmurze chrześcijańskiej Europy: mity a rzeczywistość historyczna, Warszawa 1987. 
Wykorzystując w swojej historycznej i politycznej retoryce ideę federacyjną, Halecki wskazywał, że idea jagiellońska w jej pierwotnej i nieskażonej postaci oznaczała praktycznie pełną integrację Litwy z Koronąa ${ }^{37}$. Naszym zdaniem, Halecki uznawał tu obecność kolonialnego charakteru stosunków między obiema częściami Rzeczypospolitej. W tym wypadku utożsamiał też Rzeczpospolitą z Polską w językowym i narodowym wymiarze. Miało to znaczenie dla argumentacji, że Kresy Wschodnie są częścią „historycznej Polski”38. Stworzenie „wspólnej Rzeczypospolitej” przyniosło „pomyślne rozwiązanie problemu idei Jagiellońskiej”, która również może istnieć tylko w oparciu o „dobrowolną zgodę" ${ }^{39}$. Dla Haleckiego unia stała się potwierdzeniem istnienia polskich osiągnięć w dziedzinie parlamentaryzmu i religijnej tolerancji.

Pod tym względem jego koncepcja historii Rzeczypospolitej zawiera również wyidealizowany obraz szlachty, walczącej o swoje prawa i wolności, oraz odpowiednie idealistyczne odczytanie aktów unii lubelskiej z 1569 r., Konstytucji 3 maja z 1791 r., a także konfederacji barskiej z 1768 r. Do „tematów litewskich i ruskich” wracał on, gdy było potrzebne udowodnienie koncepcji związku federacyjnego i republikańskiego charakteru Rzeczypospolitej.

Doświadczenie dyplomatyczne Haleckiego jako eksperta od spraw narodowościowych, zdobyte w Paryżu i Genewie w latach 1919-1921, przekonywało go o skuteczności przedstawienia posiadanych praw językowych, religijnych i narodowych. Proponowany przez niego język opisu Rzeczypospolitej miał być podstawą roszczeń do „ziem historycznych”, które nie zostały uznane za polskie zdobycze kolonialne. Przykładem praktycznego użycia takiego języka była retoryka delegacji polskiej podczas paryskiej konferencji pokojowej: „Litwa etnograficzna”, "historyczna Polska”, „Rusini”, „Kresy Wschodnie”, „granice z 1772 r.”

Istotą polityki Piłsudskiego, zdaniem Haleckiego podobnie jak całej historii Rzeczypospolitej, była obrona przed zachodnim i wschodnim imperializmem $^{40}$. Dla niego było bardzo ważne, aby pokazać i udowodnić, że przeszłość Polski to walka świata chrześcijańskiego przeciwko wschodniemu despotyzmowi i barbarzyństwu. Rosję, a nawet całą Azję,

37 O. Halecki, Idea Jagiellońska, s. 488.

${ }^{38}$ Dekonstrukcję mitu o Kresach Wschodnich oraz analizę jego sakralizacji w polskiej świadomości narodowej przeprowadził francuski historyk Daniel Beauvois, Mit „kresów wschodnich” czyli jak mu położyć kres, w: Polskie mity polityczne XIX i XX wieku, red. W. Wrzesiński, Wrocław 1994, s. 93-105.

39 o. Halecki, Dzieje Unii Jagiellońskiej, t. 2, s. 339-340.

${ }^{40}$ O. Halecki, The Historical Role of Central-Eastern Europe, „Annals of the American Academy of Political and Social Science" 8, marzec 1944, s. 14. 
postrzegał jako „innych”. To jak najbardziej pasowało do wybranej przez niego strategii doboru faktów i konstrukcji języka opisywania dziejów. Na tym właśnie opiera się jego koncepcja podziałów Europy.

Właśnie współpraca, a potem zderzenie dwóch reżimów totalitarnych (hitlerowskich Niemiec i stalinowskiej Rosji) doprowadziły do okupacji polskich ziem historycznych i większości obszaru Europy ${ }^{41}$. Okupacja Polski przez Niemców, a po wojnie narzucenie hegemonii radzieckiej skłoniły Haleckiego do ponownego wykorzystania koncepcji dwudzielności „między Niemcami a Rosją” oraz wyjaśnienia istoty imperializmu i jego typów. Na podstawie tej dychotomii sformułował on swoją koncepcję „Europy Środkowo-Wschodniej” (ang. East-Central Europe), w której decydującą cechą jest walka „nowych" narodów o wolność ${ }^{42}$.

W 1944 r. Halecki opublikował słynny esej The Historical Role of Central-Eastern Europe, istotny dla zrozumienia ewolucji jego poglądów historycznych. Rozważał w nim historyczne znaczenie Europy Środkowej i Wschodniej, gdzie realizowano ideę federacyjną i jagielloński system władzy. Próbował uzasadnić historyczną „wyjątkowość” Europy Środkowej pod kątem jej przynależności do Zachodu.

Słowiańskie narody regionu, w jego interpretacji, zawsze były pod czyimś panowaniem - rzymskim, niemieckim lub tureckim. Halecki skrytykował rzymską (imperialną) tradycję i wskazał jako przykład Europę Północno-Wschodnią, która jej nie znała ${ }^{43}$. Dalej pisał o „elemencie słowiańskim" w Europie Środkowej i Wschodniej, który nigdy nie dominował tam politycznie. Na koniec badacz sformułował najważniejszą dla niego teorię o opozycji „między Niemcami i Azją” i usunął Rosję z europejskiego kontekstu historycznego. Rosja zawsze należała do Wschodu - do „Azji” i jest produktem azjatyckich tradycji politycznych.

W tekście tym Halecki wyróżnił trzy systemy polityczne w Europie Środkowej i Wschodniej: federalizm w ramach idei jagiellońskiej, imperializm w wymiarze rosyjskim i system władzy Habsburgów. Rzeczpospolita w tym schemacie była postrzegana jako federacja środkowoeuropejska wzorowana na jagiellońskim systemie władzy. Wspierała się na dwóch filarach: uznaniu prawa do swobodnego rozwoju narodowego oraz na zasadzie wspólnej obrony przeciwko imperializmom wschodniemu i zachodniemu. Pisząc o potrójnym charakterze związku między Polakami, Litwinami i Rusinami, Halecki najbardziej sceptycznie oceniał

41 O. Halecki, The Sixth Partition of Poland, „The Review of Politics” 7, 1945, 2, s. $142-155$.

${ }^{42}$ O. Halecki, The Historical Role of Central-Eastern Europe, s. 16.

${ }^{43}$ Ibidem, s. 10. 
rolę tych ostatnich. Jego zdaniem, możliwości rozwoju konstytucyjnych i parlamentarnych form władzy na ziemiach ukraińskich i białoruskich przez historyków były oceniane zbyt optymistycznie ${ }^{44}$.

Paradoks takich interpretacji przejawiał się w tym, że uznając istnienie głębokich różnic między polskimi i ruskimi ziemiami na poziomie cywilizacyjnym i kulturowym, Halecki traktował Rzeczpospolitą jako państwo demokratyczne i federalne, stworzone na zasadzie dobrowolności. Pojawienie się koncepcji federacyjnych wśród małych narodów wyjaśniał położeniem „między Niemcami a Rosją”.

W jakim stopniu takie podejście Haleckiego było oryginalne? $\mathrm{Na}$ początku XX w. polskie projekty federacyjne pojawiały się w kontekście położenia „między Niemcami a Rosją"45. Po upadku imperiów i w czasie kształtowania się państw narodowych federalizm przekształcił się w ideologię taktyczną, której celem było uznanie ich niepodległości. Jak wiadomo, wielu ówczesnych polityków narodowych zgadzało się na federalizację swoich krajów, jeśli miałoby to zapewnić im możliwość przyłączenia innej przestrzeni etnicznej lub „ziemi historycznej”. Moim zdaniem, wszystkie te idee federacyjne były tylko elementem kształtowania się państw narodowych. W rzeczywistości były modelami konsolidacji „narodowej przestrzeni”, a także koncepcjami polityki zagranicznej.

Dlatego warto dodać, że ówczesny polski federalizm był raczej narzędziem polityki wschodniej, a nie prawdziwym programem kształtowania federalnej państwowości. Stąd wynikała późniejsza interpretacja Haleckiego, według której Europa Środkowa to przestrzeń jednoznacznie antyrosyjska, a Rosję i Niemcy należy traktować jako „innych”. Takie podejście miało wpływ na kształtowanie się nowoczesnej tożsamości narodowej państw tego regionu. Wtedy idea „Europy Środkowej” zaczęła zawierać zasadę wyłączenia i zamknięcia „wyobrażanych” granic narodów ${ }^{46}$.

W związku z tym różne schematy federacyjne można traktować jako przejawy odpowiedniej argumentacji w czasach kształtowania się granic nowych państw narodowych, które powstawały po I i II wojnie światowej. Faktycznie, federalizm był najmniej szczerą koncepcją, a wiara w możliwość jego wprowadzania w krajach Europy Środkowej i Wschodniej

${ }^{44}$ Ibidem, s. 12-18.

${ }^{45}$ W. Borodziej, B. Brzostek, M. Górny, Polnische Europa-Pläne des 19. und 20. Jahrhunderts, w: H. Duchhardt, M. Morawiec, I. Romsics, W. Borodziej, Option Europa. Deutsche, polnische und ungarische Europapläne des 19. und 20. Jahrhunderts, t. 1, Göttingen 2005, s. 43-134.

${ }^{46}$ Ш. Троебст, „Восток-это другое!” Центральная Европа как эксклюзионистский проект, w: Славяне и Центральная Европа. Языки, история, культура, red. Е.Н. Ковтун et al., Москва 2015, s. 63 (oryg. niem. 2012). 
była raczej wymuszona retoryką polityczną, historiograficzną i dyplomatyczną. Oczywiście, wszystkie te aspekty rozumiał i przyjmował Halecki, a więc federalizm stał się dla niego narzędziem historycznej analizy. Udowadniają to jego teksty o historii politycznej lub eseje publicystyczne. „W związku z tym - Halecki pisał w 1948 r., - wielokrotnie wskazywano, że w żadnym innym regionie świata taka dobrowolna, lokalna federacja nie jest bardziej potrzebna niż w tak zwanej Europie Centralno-Wschodniej, a raczej w Europie Środkowo-Wschodniej, gdzie kilkanaście stosunkowo małych narodów, położonych pomiędzy Niemcami i Rosją, mają szczególną potrzebę bezpieczeństwa poprzez współpracę" ${ }^{47}$. Trzeba jednak przyznać, że mimo to historyk wierzył w możliwość realizacji tej idei jeszcze w latach 1918-1923. Badania Haleckiego nad federalizmem w tym okresie były poszukiwaniem paraleli z nowoczesnymi ideałami Ligi Narodów odpowiadającymi wyzwaniom XX w. ${ }^{48}$

Halecki zawsze próbował pokazać i udowodnić inny wymiar tego zagadnienia. Dlatego rozumienie federalizmu w jego twórczości warto rozpatrywać na dwóch płaszczyznach: zjawiska historycznego i koncepcji politycznej. Uzasadniał on znaczenie federalizmu jako udanej historycznej praktyki na przykładzie Unii Jagiellońskiej ${ }^{49}$. Miał on być przykładem do naśladowania dla innych krajów Europy Środkowo-Wschodniej, ale również realistycznym scenariuszem wyjścia spod dominacji niemieckiego i rosyjskiego imperializmu. Dla wzmocnienia tej tezy Halecki porównał unię kalmarską i unię Polski z Litwą. Oparł się tu na interpretacji norweskiego historyka Haldvana Kohta, przedstawionej na międzynarodowym kongresie historyków w Warszawie w 1933 r. ${ }^{50}$

Halecki postrzegał Europę Wschodnią w wymiarze cywilizacyjnym i geograficznym. Po zakończeniu II wojny światowej nie traktował jej w „postjałtańskim” rozumieniu, czyli jako „radzieckiej strefy wpływów”, która powstała na wschód od „żelaznej kurtyny” w drugiej połowie lat czterdziestych. Zdaniem polskiego historyka Tomasza Stryjka, koncepcja Haleckiego z 1950 r. dotycząca Europy Środkowo-Wschodniej była

47 „In that connection it has been pointed out time and again that in no other region of the world is such a voluntary, local federation more badly needed than in so-called central-eastern, or rather east-central Europe, where a dozen comparatively small nations, situated between Germany and Russia, have a special need of security through cooperation”, O. Halecki, Federalism as an Answer, „Annals of the American Academy of Political and Social Science" 258, lipiec 1948, s. 66.

${ }^{48}$ M. Kornat, Profesor Oskar Halecki, s. 236.

${ }^{49}$ O. Halecki, Federal Traditions in Central Eastern Europe, „New Europe” 1 XII 1940, s. $11-12$.

50 Zob. O. Halecki, Unia Polski z Litwa a Unia Kalmarska, w: Studia historyczne ku czci Stanisława Kutrzeby, t. 1, Kraków 1938, s. 217-232. 
najbliższa „amerykańskiemu” spojrzeniu na kraje tego regionu ${ }^{51}$. Jednak badacz naprawdę odrzucał taką wizję Europy Wschodniej i dlatego zdecydował się „przypomnieć” Zachodowi o Europie Środkowej. Przecież dla niego wolność narodów wschodnioeuropejskich, ich powrót do cywilizacji zachodniej były możliwe tylko po wyjściu spod rosyjskiej (radzieckiej) dominacji i dlatego nie mogły być one „strefą wpływów”. Zaproponował interpretację dziejów Europy jako chrześcijańską polemikę z marksistowską wizją materializmu historycznego ${ }^{52}$.

Innego zdania był węgierski eseista i myśliciel polityczny István Bibó. Przekonywał, że historia Europy Środkowej i Wschodniej zawiera mnóstwo różnych mesjanistycznych koncepcji, idei o szczególnej misji w obronie kultury, chrześcijaństwa i demokracji ${ }^{53}$. Ironia stwierdzenia węgierskiego intelektualisty o nędzy narodów wschodnioeuropejskich polegała na krytyce "językowego" nacjonalizmu, który pojawił się jako reakcja na historyczną sytuacje „między Francją a Rosją"54. Halecki natomiast postrzegał to poważnie: krytykując imperializm i panslawizm formułował myśli o środkowoeuropejskim federalizmie jako relewantnej odpowiedzi na usytuowanie „między Azją i Rosją"55.

Powstaje tu jednak pytanie, jaką Europę Środkową i Wschodnią zachodnie elity były gotowe uznać za rzeczywistość historyczną. Odpowiedź Haleckiego była jednoznaczna. Jeśli Polska, Czechy, Węgry, kraje bałtyckie prezentują podobny do cywilizacji zachodniej model polityczny i społeczny, to czy można kraje tego regionu uznać za rosyjską strefę wpływów? Oczywiście, dla Haleckiego porządek europejski po konferencji jałtańskiej w 1945 r. w dużej mierze przypominał układ międzynarodowy ustalony po kongresie wiedeńskim w 1815 r., kiedy Rosja dokonała kolejnego „powrotu” do Europy ${ }^{56}$.

Swoje przekonania Halecki wyraził w 1950 r. Wtedy ponownie spróbował określić granice Europy w jednej ze swoich najważniejszych prac The Limits and Divisions of European History ${ }^{57}$. Proponował on podział Europy na

${ }^{51}$ T. Stryjek, Europa Środkowa (Środkowo-Wschodnia), czyli o pochwale różnorodności i komparatystyki, KH 120, 2013, 4, s. 765.

${ }^{52}$ M. Todorova, Bałkany wyobrażone, Wołowiec 2014, s. 323 (oryg. ang. 1997).

53 I. Bibó, Nędza małych państw wschodnioeuropejskich, w: idem, Eseje polityczne, Kraków 2012, s. 82.

54 Ibidem, s. 50.

55 O. Halecki, Imperialism in Slavic and East European History, „The American Slavic and East European Review" 11, 1951, 1, s. 6.

56 O. Halecki, Wschód europejski, Polska a Rosja, „Wiadomości”, London, 29 IX 1957.

57 O. Halecki, The Limits and Divisions of European History, London-New York 1950. W tym artykule będziemy korzystać z polskiego tłumaczenia: Historia Europy. Jej granice i podziały, Lublin 1994. 
cztery regiony - Zachodni, Środkowo-Zachodni, Wschodnio-Środkowy i Europę Wschodnią sensu stricto. Ten model można rozpatrywać w perspektywie longue durée $e^{58}$, a powstał on jako reakcja na politykę „podziału na strefy wpływów". Amerykański i polski historyk Piotr Wandycz uważał, że w tej pracy Halecki sformułował ważną pozycję: „Historyczna Europa nie zawsze odpowiadała granicom Europy w sensie geograficznym, dlatego badając jej przeszłość, nie należy się ograniczać tylko do jednej z części” 59 .

Główne pytanie, jakie formuje Halecki, to: „Czym jest historia europejska?". Polemizując z Jaroslavem Bidlo, Arnoldem Toynbee i Hugh Seton-Watsonem, formułuje odpowiedź: historia Europy - to przede wszystkim proces transformacji cywilizacji grecko-rzymskiej połączonej chrześcijaństwem ${ }^{60}$. Tutaj znowu pojawia się dychotomia „między Niemcami i Rosją" i wybrzmiewa teza o podobieństwie niemieckiej i rosyjskiej filozofii politycznej ${ }^{61}$. Wychodząc od tego, Halecki wyróżnia dwa regiony „Europy Środkowej”62. Pierwsza Europa Środkowa (ang. West Central Europe) postrzegana jest jako teren dawnego Świętego Cesarstwa Rzymskiego, a na początku XX w. to Niemcy, północne Włochy i zachodnie części Austro-Węgier. Druga Europa Środkowa - to Europa Środkowo-Wschodnia (ang. East Central Europe), która obejmuje Polskę (ziemie Rzeczypospolitej), Czechosłowację, ziemie Korony Węgierskiej, kraje bałtyckie i Finlandię, Grecję, oraz ziemie ukraińskie i białoruskie, pod warunkiem ich wyjścia spod rosyjskiego panowania. Właśnie dlatego Halecki zawsze podkreślał rolę Polski w tym regionie, kiedy „za Jagiellonów Polska stanowiła centrum federacji, która w pewnym momencie składała się z Czech, Węgier i księstw rumuńskich”. W efekcie „federacja ta na wiele stuleci łączyła Polskę z Litwą, Rusią (dzisiejszą Ukrainą i Białorusią), Łotwą i częścią Estonii w ramach jednej Rzeczypospolitej”63. Jak widać, Halecki po prostu utożsamiał Polskę z Europą Środkowo-Wschodnią.

Proponowana koncepcja „Europy Środkowej” powstała wcześniej niż pojęcie „Europa Środkowo-Wschodnia”, a Rosja została usunięta z obu

58 S. Troebst, Halecki Revisited. Europe's Conflicting Cultures of Remembrance, w: Cultural Memories. The Geographical Point of View, red. P. Meusburger M. Heffernan, E. Wunder, Dordrecht-Heidelberg 2011, s. 145-154.

59 P. Wandycz, Oskar Halecki i jego koncepcja, s. 46.

${ }^{60}$ Ibidem, s. 34.

${ }^{61}$ O. Halecki, Historia Europy, s. 134. Halecki odwoływał się do dwóch tekstów: J. Kucharzewski, German Philosophy and the Russian Intelligentsia, „Bulletin of the Polish Institute” 1944, 2, s. 1057-1076; N. Berdyaev, The Russian Idea, New York 1948, s. 40, 42, 51, 74.

62 O. Halecki, Historia Europy, s. 121-136.

${ }^{63}$ Ibidem, s. 131. 
Europ. Pod wpływem Arnolda Toynbee i Georgija Wiernadskiego Halecki postrzegał Rosję jako specjalny kontynent: Eurazję oraz główne zagrożenie dla Europy Wschodniej - przestrzeni między Świętym Cesarstwem Rzymskim i euroazjatycką Rosją ${ }^{64}$.

Oczywiście, instrumentalizacja takiego schematu była efektem wpływu światopoglądu religijnego i sposobem obrony interesów politycznych. W aspekcie chrześcijańskim jest to dwudzielne rozumienie świata, jako walki dobra i zła. W starożytnym Rzymie wysoko rozwinięte i ucywilizowane Południe przeciwstawiało się opóźnionej w rozwoju Północy, która była związana z plemionami barbarzyńskimi ${ }^{65}$. Halecki także podjął temat zdefiniowania „innego”, zagadnienia obecnego w pracach historyków po I wojnie światowej. Udowodnienie „inności” można uznać za udany model „narodowej konsolidacji”.

Do Europy Środkowo-Wschodniej w wymiarze geograficznym i cywilizacyjnym Halecki zaliczył Węgry, Czechy, Słowację, Grecję, Finlandię, Łotwę, Estonię, ziemie unii polsko-litewskiej i starą Ruś, czyli ziemie ukraińskie i białoruskie, wchodzące w skład dawnej Rzeczypospolitej. Ciekawe, że wyraźnie widział on Europę Środkową jako region cywilizacji zachodniej, jednak wskazywał na pewne odmienności. Taki pogląd w pełni odpowiadał jego „geografii mentalnej”. Nie analizował on rozwoju tożsamości etnicznej i narodowej, przyjmując je za „rzeczywisty fakt”. Mimo to przyjął pogląd o „strefach wpływu” w ramach determinizmu geograficznego.

W książce Borderlands of Western Civilization. A History of East Central Europe (1952) już we wstępie przedstawił wschodnią część Europy Środkowej jako region obejmujący ziemie na północ od Karpat, kraje naddunajskie i Bałkany. Jednak te "granice" okazały się niewystarczające dla sformułowania idei „Wielkiego Europejskiego Przesmyku” (ang. Great European Isthmus), którym, jego zdaniem, był region od Morza Bałtyckiego do Morza Czarnego. Badacz zmienił tu nieco koncepcję „Międzymorza" - utopię stworzenia unii konfederacyjnej Finlandii, Polski, krajów nadbałtyckich, Białorusi i Ukrainy ${ }^{66}$. W tej pracy Halecki traktował Europę Środkowo-Wschodnią jako peryferie Zachodu, wykazując rolę pogranicza nie jako miejsca cywilizacyjnego i kulturowego współdziałania, a przestrzeni walki z Azją.

${ }^{64}$ Ibidem, s. 132-133; J. Kłoczowski, Europa Środkowowschodnia, s. 20.

${ }^{65}$ И. Нойманн, Использование Другого. Образы Востока в формировании европейских идентичностей, Москва 2004, s. 221 (oryg. ang. 1999.)

${ }^{66}$ Zob. P. Okulewicz, Koncepcja „międzymorza” w myśli i praktyce politycznej obozu Józefa Piłsudskiego w latach 1918-1926, Poznań 2001. 
Mimo to postrzegał kraje demokracji ludowej w Europie Środkowej i Wschodniej jako skradzioną część „Zachodu”, do którego już zaliczał Europę Zachodnią wraz z „Europą Zachodnio-Środkową” i „Europą Wschodnio-Środkową" ${ }^{67}$. Z tego powodu wciąż próbował wyjaśnić rolę Rosję w historii europejskiej. Wrócił również do kwestii „granicznych ziem cywilizacji zachodniej”. "Jak tylko Moskwa rozwinęła się w nowe imperium - pisał - historia tej nowej Rosji stała się nieodłączna od historii Europy w ogóle"68. Tym samym powtarzał znaną ocenę reform rosyjskiego cara Piotra Wielkiego i uznał ich znaczenie dla transformacji „azjatyckiej” Moskwy w „europejską” Rosję. Nie oznacza to jednak, że uznawał rosyjską historię jako część europejskiej. Podobnie więc samych „rosyjskich” ziem, wchodzących wcześniej w skład księstw ruskich, Halecki nie traktował jako całość, co pozwalało w przyszłości uzasadniać „prawa historyczne” Rzeczypospolitej do nich.

Rozpad dawnej Rusi oznaczał koniec jej historii europejskiej: przerwanie kijowskiej tradycji państwowej i rozwój włodzimierskiej, a potem moskiewskiej stał się początkiem „azjatyckiej” Moskwy. Ostateczne odrodzenie państwowości moskiewskiej miało miejsce po zrzuceniu dominacji mongolskiej, „kiedy nowa skolonizowana Rosja (Europa Wschodnia w sensie geograficznym) zaczęła się rozwijać poza tradycjami europejskimi" ${ }^{\circ}$.

W tej interpretacji Halecki miał poglądy podobne do Michaiła Pogodina (Mihail Pogodin), który wpłynął na rozwój schematu historii rosyjskiej. W odpowiedzi na to, ukraiński historyk Mychajło Hruszewski (Mihajlo Grušews'kij) w 1904 r. zaproponował własny schemat dziejów Słowian wschodnich, który udowadniał bezpośredni, dziedziczony rozwój tradycji Rusi Kijowskiej od Księstwa halicko-włodzimierskiego do państwa litewsko-ruskiego. Kijowska państwowość, prawo i kultura, według Hruszewskiego, zostały stworzone przez narodowość rusko-ukraińską, a państwowość włodzimierska wyrosła z innego korzenia ${ }^{70}$. Można powiedzieć, że w tym starym sporze Halecki okazał się bliżej Pogodina. Użył przyjętego schematu historii rosyjskiej, aby wykazać skłonnność Rosji do przyjmowania azjatyckich tradycji społeczno-politycznych. To stwierdzenie stało się podstawą konstruowanych granic Europy Środkowej

${ }^{67}$ S. Troebst, What's in a Historical Region, s. 174.

68 O. Halecki, Borderlands of Western Civilization. A History of East Central Europe, New York 1952, s. 3.

69 Ibidem, s. 77.

70 М. Грушевський, Звичайна схема „русскоі” історії й справа раціонального укладу icmopiï східного слов'янства, Статьи по славяноведению, wyd. 1, Санкт-Петербург 1904, s. 299-300. 
(z odmianami - „Środkowo-Wschodniej” i „Centralnej”) jako wyjątkowo antyrosyjskiej przestrzeni.

Uzasadnienie podziału Europy na cztery regiony znalazło odzwierciedlenie w syntetycznej pracy o dziejach europejskich pt. The Millennium of Europe $^{71}$, w której przedstawił cywilizacyjną misję katolicyzmu i Polaków na wschodzie Europy. Książka stała się syntezą całej działalności naukowej Haleckiego: rolą Polski jest umocnienie religijnie i cywilizacyjne na obszarze Europy Wschodnio-Środkowej.

Summa summarum, wizja Haleckiego „dwóch Europ Środkowych” była próbą wykazania braku jakichkolwiek różnić politycznych czy kulturowych między Zachodem i ,inną” Europą. Chodziło mu o istnienie wspólnego korzenia, łączącego narody europejskie: chrześcijaństwa i ideału swobody. Zaproponowany przez Haleckiego środkowoeuropejski dyskurs można traktować jako swoisty apel do Zachodu, który można wytłumaczyć w kategoriach geografii mentalnej. Jak prześledziliśmy, opierał się on na dychotomii „między Niemcami a Azją”, kształtując granice cywilizacyjne i historyczne „Europy Środkowo-Wschodniej”. Zdaniem badacza był to obszar „pogranicza Zachodu”, który łączył elementy zachodnich tradycji politycznych, katolicyzm obu obrządków oraz niektóre ważne osiągniecia kultury wschodniej. Traktując Polskę jako „ostatni bastion” Zachodu i chrześcijaństwa, Halicki krytykował teksty przedstawicieli oficjalnej historiografii krajów „demokracji ludowej”. W centrum historii europejskiej widział państwo narodowe, złączone wartościami chrześcijańskimi, bez których nie może istnieć społeczeństwo wolne i demokratyczne.

$\mathrm{Na}$ tej podstawie Halecki doszedł do koncepcji cywilizacyjno-kulturowego podziału Europy na cztery części. Jednak oczywiste jest, że jego wizja podziałów kontynentu była raczej dwudzielna. Można to zinterpretować następująco: pierwszy region to jest „prawdziwa” Europa od Kijowa do Lizbony. Drugi, to prawosławna Moskowa (później Rosja), a w rzeczywistości Eurazja. Jego „rzeczywista Europa” zawiera „dwie Europy Środkowe”, które powstały jako reakcja na położenie „między Niemcami a Rosją (Azją)". Przeanalizowany model historiograficzny Haleckiego można również ocenić jako dzieło geopolityczne i ideologiczne.

${ }^{71}$ O. Halecki, The Millennium of Europe, Paris 1963, s. 441. 


\section{Streszczenie}

Niniejszy artykuł prezentuje problematykę pojęcia „Europa Środkowa” w koncepcjach wybitnego polskiego historyka Oskara Haleckiego (1891-1973). Jest on uważany za autora pojęcia „Europa Środkowo-Wschodnia”. Moim celem była analiza istoty, ewolucji i instrumentalizacji tej definicji w pracach historyka, a w szczególności - koncepcji „dwóch Europ Środkowych” jako alternatywy zachodnich percepcji wschodu Europy.

Halecki w ciągu swojego życia sformułował dwie ważne koncepcje. Pierwszą z nich była „Europa Wschodnia”, którą przedstawił w licznych artykułach, poczynając od 1919 r., a której trzymał się aż do wybuchu II wojny światowej. Według niego, było to pojęcie czysto geograficzne, a nie cywilizacyjne, i obejmowało terytorium dawnej Rzeczypospolitej i innych ziem na północ od Karpat (zachodnie kresy Imperium Rosyjskiego). Drugą z nich była koncepcja „Europy Środkowo-Wschodniej”, sformułowana już na emigracji po wojnie. Halecki postrzegał ją w wymiarze cywilizacyjnym i geograficznym, nie traktując jako terytorium położonego w rosyjskiej strefie wpływów. Do obszaru „Europy Środkowo-Wschodniej” włączał Polskę, Czechosłowację, ziemie Korony Węgierskiej, kraje bałtyckie, Finlandię, i warunkowo ziemie ukraińskie i białoruskie. Z obu swoich koncepcji usunął Rosję, traktując ją jako osobny „kontynent” oraz główne zagrożenie dla Europy Wschodniej. Na tych podstawach Halecki doszedł do koncepcji podziału Europy na cztery części, jednakże jasne jest, iż była ona raczej dwudzielna (od Lizbony do Kijowa - to Europa, a Rosja - to Eurazja). Spojrzenie Haleckiego wywarło duży wpływ na późniejszą historiografię, ale też oddziałuje na współczesną politykę historyczną w Europie Środkowo-Wschodniej.

\section{Oskar Halecki's "Dualism of Central Europe" in the "Shadow of Imperialism"}

The article presents the notion of Central Europe in concepts of the outstanding Polish historian Oskar Halecki (1891-1973). He is considered the father of the term "East Central Europe". The purpose of the present study is to analyse the essence, evolution and instrumentalization of this definition in Oskar Halecki's works, and especially of the concept of "dualism of Central Europes" as the alternative of Western perceptions of Eastern Europe.

Halecki formulated two important concepts during his life. The first one was that of "Central Europe", put forward in a number of his articles between 1919 and the outbreak of World War II. According to Halecki, it was a purely geographical notion, not a civilisation one, and it included the territories of the old Polish-Lithuanian Commonwealth and other lands north to the Carpathian Mountains (the western borderlands of the Russian Empire).

Halecki's second concept was the concept of "East Central Europe", formulated after the war, when he had left Poland. Halecki saw it as a civilisation and geographical notion, not regarding it as the area within the Russian zone of influence. 
The territory of "East Central Europe" included Poland, Czechoslovakia, the lands of the Kingdom of Hungary, the Baltic states, Finland, and - conditionally - Ukrainian and Belarusian lands. He removed Russia from both of his concepts, regarding it as a special continent and a main threat to Eastern Europe. On this basis, Halecki developed the concept of division of Europe into four parts, but it was evident that division was dichotomous rather than four-part (between Lisbon and Kiev - was Europe, while Russia was Eurasia). Halecki's perspective had a great impact both on later historiography and contemporary historical politics in East Central Europe.

Translated by Grażyna Waluga

\section{Bibliografia}

Beauvois Daniel, Mit „kresów wschodnich” czyli jak mu położyć kres, w: Polskie mity polityczne XIX i XX wieku, red. Wojciech Wrzesiński, Wydawnictwo Uniwersytetu Wrocławskiego, Wrocław 1994, s. 93-105.

Berdyaev Nicolas, The Russian Idea, Macmillan Company, New York 1948.

Bibó István, Nędza małych państw wschodnioeuropejskich, w: Bibó István, Eseje polityczne, Universitas, Kraków 2012, s. 22-98.

Błachowska Katarzyna, Oskar Halecki (1891-1973), w: O. Halecki, Dzieje Unii Jagiellońskiej, t. 2: W XVI wieku, oprac. Katarzyna Błachowska, IH UW, Neriton, Warszawa 2013.

Borodziej Włodzimierz, Brzostek Błażej, Górny Maciej, Polnische Europa-Pläne des 19. und 20. Jahrhunderts, w: Heinz Duchhardt, Malgorzata Morawiec, Ignac Romsics, Włodzimierz Borodziej, Option Europa. Deutsche, polnische und ungarische Europapläne des 19. und 20. Jahrhunderts, t. 1, Vandenhoeck \& Ruprecht, Göttingen 2005, s. 43-134.

Cisek Janusz, Oskar Halecki. Historyk. Szermierz Wolności, IPN, Warszawa 2009.

Europa Współczesna, część ogólna. Rok akad. 1931-32, według wykładów prof. Oskara Haleckiego, T-wo Br. Pom. Studentów Szkoły Nauk Politycznych, Warszawa [1932?].

Górny Maciej, Przede wszystkim ma być naród. Marksistowskie historiografie w Europie Środkowo-Wschodniej, TRIO, Warszawa 2007.

Górny Maciej, Użyteczność i granice. Europa Środkowo-Wschodnia jako narzędzie badawcze, KH 120, 2013, 4, s. 801-808.

Grzybowski Konstanty, Anachroniczna historiozofia profesora Oskara Haleckiego, w: idem, Refleksje sceptyczne, t. 1, Książka i Wiedza, Kraków 1972, wyd. II, s. $65-76$.

Halecki Oskar, Borderlands of Western Civilization. A History of East Central Europe, The Ronald Press Company, New York 1952.

Halecki Oskar, Czy potrzebna jest „rewizja” dziejów Polski, „Przegląd Powszechny” 204, 1934, 612, s. 295-314.

Halecki Oskar, Dzieje Unii Jagiellońskiej, t. 1: W wiekach średnich, t. 2: W XVI wieku, Akademia Umiejętności, Nakładem Funduszu Nestora Bucewicza, Kraków 1919-1920. 
Halecki Oskar, Ekspansya i tolerancya, w: Przyczyny upadku Polski. Odczyty, Gebethner i Wolff, Warszawa 1918, s. 4-77.

Halecki Oskar, Federal Traditions in Central Eastern Europe, „New Europe” 1 XII 1940, s. 11-12.

Halecki Oskar, Federalism as an Answer, „Annals of the American Academy of Political and Social Science" 258, Jul. 1948, s. 66-69.

Halecki Oskar, Historia Europy. Jej granice i podziały, Instytut Europy Środkowo-Wschodniej, Lublin 1994.

Halecki Oskar, Idea Jagiellońska, KH 51, 1937, 1-2, s. 486-510.

Halecki Oskar, Imperialism in Slavic and East European History, „The American Slavic and East European Review" 11, 1951, 1, s. 1-26.

Halecki Oskar, Kijów a Polska, „Tygodnik Ilustrowany” 1920, 20, s. 382.

Halecki Oskar, L'histoire de l'Europe orientale. Sa division en époques, son milieu géographique et ses problèmes fondamentaux, w: La Pologne au V Congrès International des Sciences Historiques, Bruxelles 1923, Varsovie 1924, s. 73-94.

Halecki Oskar, The Historical Role of Central-Eastern Europe, „Annals of the American Academy of Political and Social Science" 8, march 1944, s. 9-18.

Halecki Oskar, The Limits and Divisions of European History, Sheed and Ward, London - New York 1950.

Halecki Oskar, The Millennium of Europe, University of Notre Dame Press, Paris 1963.

Halecki Oskar, The Sixth Partition of Poland, „The Review of Politics” 7, 1945, 2, s. $142-155$

Halecki Oskar, Unia Polski z Litwa a Unia Kalmarska, w: Studia historyczne ku czci Stanisława Kutrzeby, t. 1, nakł. Komitetu, Kraków 1938, s. 217-232.

Halecki Oskar, Wschodnia granica Polski w świetle historii, „Przegląd Dyplomatyczny” 1, 1919, 2, s. 45-57.

Halecki Oskar, Wschód europejski, Polska a Rosja, „Wiadomości”, London, 29 IX 1957. Kłoczowski Jerzy, Europa Środkowowschodnia w historiografii krajów regionu, Lublin 1993 (Materiały Instytutu Europy Środkowo-Wschodniej, t. 5).

Kłoczowski Jerzy, Oskar Halecki i jego walka o miejsce Polski w Europie, w: Z dziejów polityki i dyplomacji. Studia poświęcone pamięci Edwarda hr. Raczyńskiego, Prezydenta Rzeczypospolitej Polskiej na wychodźstwie, red. Henryk Bułhak, Wydawnictwo Sejmowe, Warszawa 1994, s. 397-406.

Kornat Marek, „Pesymizm” czy „optymizm”? Oskar Halecki a spór o wartość dziejowej spuścizny przedrozbiorowej Rzeczypospolitej w historiografii polskiej, w: Oskar Halecki i jego wizja Europy, t. 2, red. Małgorzata Dąbrowska, IPN, Warszawa-Łódź 2014, s. 67-90.

Kornat Marek, Historyk Europy Środkowo-Wschodniej. Oskar Halecki (1891-1973) w nauce i życiu Polski, w: Historik v proměnách doby a prostředi 20. stoleti, red. Jiří Hanuš, Radomir Vlček, Matice moravská, Brno 2009, s. 305-338.

Kornat Marek, Profesor Oskar Halecki w życiu politycznym Polski i na forum międzynarodowym, w: Oskar Halecki i jego wizja Europy, t. 3, red. Małgorzata Dąbrowska, IPN, Warszawa-Łódź 2014, s. 275.

Kucharzewski Jan, German Philosophy and the Russian Intelligentsia, „Bulletin of the Polish Institute" 1944, 2, s. 1057-1076. 
Łukasiewicz Sławomir, Trzecia Europa. Polska myśl federalistyczna w Stanach Zjednoczonych 1940-1971, IPN, Warszawa-Lublin 2010.

Miller Aleksiej, Koncepcje regionalnego podziału Europy to przedmiot badań geografii mentalnej. I tyle, $\mathrm{KH} \mathrm{120,} \mathrm{2013,} \mathrm{4,} \mathrm{s.} \mathrm{861-864.}$

Morawiec Małgorzata, Oskar Halecki, w: Europa-Historiker. Ein biographisches Handbuch, red. Heinz Duchhardt, Vandenhoeck and Ruprecht, Göttingen 2006, s. $215-239$.

Okulewicz Piotr, Koncepcja „międzymorza” w myśli i praktyce politycznej obozu Józefa Piłsudskiego w latach 1918-1926, Wydawnictwo Poznańskie, Poznań 2001.

Stobiecki Rafał, Historycy polscy wobec wyzwań XX wieku, Nauka i Innowacje, Poznań 2014.

Stobiecki Rafał, Twórczość emigracyjna Oskara Haleckiego (1891-1973). Próba charakterystyki, w: Studia z dziejów Polski i Europy w XIX i XX wieku. Księga dedykowana Profesorowi Piotrowi Stefanowi Wandyczowi, red. Janusz Faryś, Roman Nir, Mark Szczerbiński, Zamiejscowy Wydział Kultury Fizycznej Poznańskiej AWF, Gorzów Wielkopolski 2004, s. 581-592.

Stryjek Tomasz, Europa Środkowa (Środkowo-Wschodnia), czyli o pochwale różnorodności i komparatystyki, KH 120, 2013, 4, s. 761-791.

Tazbir Janusz, Fałsz historyczny $i$ zdrada narodu w pracach O. Haleckiego, KH 60, 1953, 3, s. 177-178.

Tazbir Janusz, Od antemurale do przedmurza. Dzieje terminu, OiRP 29, 1984, s. 166-184. Tazbir Janusz, Polskie przedmurze chrześcijańskiej Europy. Mity a rzeczywistość historyczna, Interpress, Warszawa 1987.

Todorova Maria, Bałkany wyobrażone, Czarne, Wołowiec 2014.

Troebst Stefan, Halecki Revisited. Europe's Conflicting Cultures of Remembrance, w: Cultural Memories. The Geographical Point of View, red. Peter Meusburger, Michael Heffernan, Edgar Wunder, Springer, Dordrecht-Heidelberg 2011, s. $145-154$.

Troebst Stefan, What's in a Historical Region? A Teutonic Perspective, „European Review of History" 10, 2003, 2, s. 173-188.

Wandycz Piotr, East European History and its meaning. The Halecki-Bidlo-Handelsman debate, w: Király Béla emlékkönyv. Háború és társadalom, red. Pál Jónás, Béla K. Király, Századvég, Budapest 1992, s. 308-321.

Wandycz Piotr, o historycznej tożsamości Europy Środkowo-Wschodniej, „Tygodnik Powszechny" 1987, 18.

Wandycz Piotr, Oskar Halecki i jego koncepcja Europy Środkowo-Wschodniej, „Rocznik Instytutu Europy Środkowo-Wschodniej" 5, 2007, s. 45-51.

Wolff Larry, Inventing Eastern Europe. The Map of Civilization on the Mind of the Enlightenment, Stanford University Press, Stanford Calif. 1994.

Грушевський Михайло, Звичайна схема „русскоі” історії й справа рациіонального укладу історії східного слов'янства, Статьи по славяноведению, wyd. 1, Санкт-Петербург 1904.

Грушевський Михайло С., Історія Украӥни-Руси: в 11 m. 12 кн, t. 3, Київ 1993.

Костомаров Николай Иванович, Мысли о федеративном начале в Древней Руси, Из журнала „Основа”, Санкт Петербург 1861. 
Нойманн Ивер, Использование Другого. Образы Востока в формировании европейских идентичностей, Новое издательство, Москва 2004.

Троебст Штефан, „Восток - это другое!” Центральная Европа как эксклюзионистский проект, w: Славяне и Центральная Европа. Языки, история, культура, red. Елена Николаевна Ковтун et al., Полимедиа, Москва 2015, s. 61-70.

Biogram: Gennadii Korolov (Геннадій Корольов) - dr, starszy pracownik naukowy w Instytucie Historii Ukrainy Narodowej Akademii Nauk Ukrainy. Główne zainteresowania badawcze: historia historiografii, historia federalizmu w Europie Środkowej i Wschodniej, historia ukraińskiej rewolucji 1917-1921; kontakt: hennadiikorolev@gmail.com. 